\title{
Reorganization of UK medical research
}

\section{MRC recovers funds from Rothschild?}

A plan for reversing the Rothschild disposition of funds for British medical research is to be considered by the Medical Research Council (MRC) at its meeting today ( 23 October). The proposal, which has already been agreed by the Cabinet and was notified to the Advisory Board for the Research Councils on Monday of last week, may involve an increase of $£ 12$ million a year in the annual budget of the MRC, now running at $£ 56$ million a year.

Both the Department of Health and MRC at the official level appear to have arrived amicably at the proposal now being decided. One argument in its favour has been the difficulty experienced in the past several years in operating an effective Chief Scientist's Department within the Department of Health. Officials of MRC have also been swayed in the direction of the proposed arrangement by the recognition that, over the past decade, the funds available for contract work from the Department of Health and the Scottish Home and Health Department have been a declining proportion of the total budget for medical research in Britain.

The council will be expected at its meeting today to strike a balance between the benefits of a larger annual budget and the commitment it will now be expected to make to applied medical research. The proposal being considered involves no explicit strings, but representatives of the Department of Health will expect to be listened to more seriously in future if the council elects to take the funds now offered. If the council accepts, the Minister of Health intends to announce its decision J.L. Gowans, MRC secretary

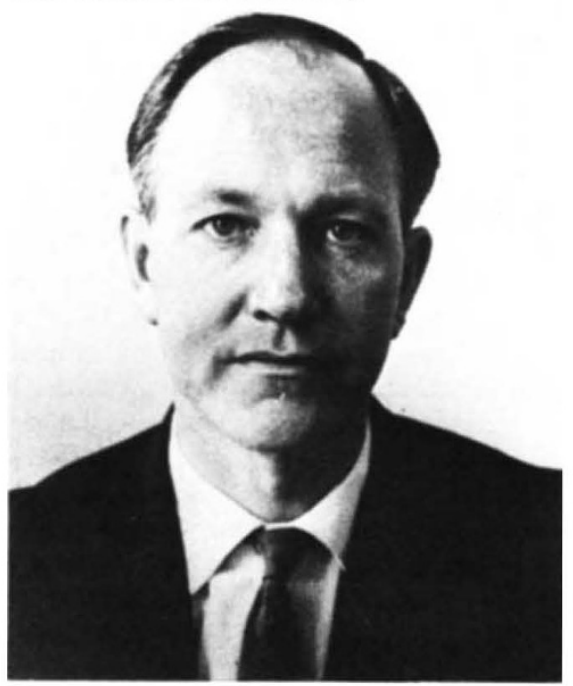

next Tuesday in the House of Commons.

Formally, the Department of Health cannot off its own bat transfer funds from its own budget to that of MRC, which is dependent on the Department of Education and Science for its annual budget. This is why the feasibility of the proposed transfer of funds has had to be approved by the Cabinet before it could carry conviction with the council. But the redisposition of funds also entails an issue of principle - the abandonment of Lord Rothschild's "customer--contractor principle", at least as far as medical research is concerned.

The Rothschild doctrine, made public in 1971 and promptly accepted by the Conservative government of the day, recommended that 25 per cent of the then MRC budget should be progressively transferred to the Department of Health in the succeeding five years and that the department should use the funds concerned to commission research, not necessarily from the MRC.

One prominent feature of the Rothschild recommendations was the suggestion that each government department should be equipped with a "strong" chief scientist's department capable of making informed judgements of the department's need for research and of deciding how (and by whom) these objectives would best be met.

At the outset, MRC was more vigorous than the other research councils in its opposition to the Rothschild proposals. MRC also stands out among the research councils for the difficulties it has found in

\section{Genentech makes splash on Wall Street}

\section{Washington}

"One of the most spectacular market debuts in recent history." That was how the Wall Street Journal described the first day of public trading in shares in Genentech, the San Francisco company which has been among the leaders of those aggressively pursuing the commercial exploitation of recombinant DNA technology.

Initially the company has proposed to offer one million shares at between $\$ 20$ and $\$ 30$ each. But demand was so great that an initial price of $\$ 35$ was fixed for members of an under writing syndicate through which the shares were made public last week. An extra 100,000 shares were made available, providing the company with an investment - once brokerage commissions had been deducted - of $\$ 36$ million.

During the day of frantic over-thecounter trading, in which more than half of the shares were resold by their original purchasers, the price rose at one point to $\$ 89$ a share, eventually dropping back to $\$ 71$. As the company has 7.5 million shares, this gives it a value of more than working out a smooth relationship with its sponsoring departments. Committees set up to suggest promising directions for applied medical research have been frustrated either by the lack of funds or the imprecision of their terms of reference. Research commissions by the Department of Health to MRC have generated uncomfortably large files of paper, while the council has been left with the sense that a substantial part of its annual spending is soft money.

At the Department of Health, difficulties have arisen because of the lack of fulltime officials with a background in research. The chief medical officer has statutory responsibilities for the health of the population, and may find a conflict of interest between his day-to-day responsibilities and the planning of research. The National Health Service, presumably the prime customer in Rothschild's sense, is, however, administratively separate from the Department of Health proper.

An affirmative decision by the council at its meeting today will require that MRC equip itself to plan and execute programmes in applied medical research ranging from clinical research to the conduct of social surveys related to the effectiveness of medical care in Britian. The prize for success could well be a budget enlarged not merely by the $£ 12$ million of Rothschild money but a substantial slice of the further $£ 14$ million spent each year by the Department of Health and the Scottish departments on commissioned research with contractors other than MRC.

\section{$\$ 500$ million.}

On paper, the Wall Street dealings have made multimillionaires of Genentech's two founders, $\mathrm{Mr}$ Robert Swanson, its president and chief executive, and Dr Herbert Boyer, vice-president and professor of biochemistry at the University of California, San Francisco.

Both own just under a million shares in the company. The principal shareholder is Lubrizol Incorporated of Cleveland, which previously bought 1.5 million shares in the company at $\$ 10$ each. Kleiner and Perkins, an east coast venture capital firm, hold almost a million shares. The remainder are divided between directors and employees of the company.

Some employees have benefited from originally being paid in shares rather than cash. Robert Scheller, for example, a graduate research student at the California Institute of Technology, was given 15,000 for helping with research on human growth hormone four years ago. The stock is now worth more than \$1 million.

The prices reached by the shares during the first day of public trading were con- 
siderably higher than most market analysts had anticipated. Two factors contributed. The first was a widespread expectation among investors that genetic engineering is the cornerstone of a future billion dollar industry, and Genentech is the only one of half a dozen small research companies to have gone public.

The second factor was a recent change in the tax law which has helped to restimulate the supply of venture capital. In 1969, Congress introduced legislation raising the effective rate of tax on long-term capital gains from 25 per cent to 48 per cent.

Many investors moved from the stock market to tax shelters, one result being a virtual drying up of new high-technology firms in the mid-1970s. In response, Congress cut the long-term capital gains tax back to 28 per cent in 1978 , contributing significantly to the fact that the number of new companies is increasing rapidly again.

Thus, despite recent government warnings about declining investment in technological innovations, there was no shortage of bidders for other Genentech stock. Many brokerage houses were unable to obtain any shares at all in the initial allocation; others who had requested 50,000 or more only received a few hundred.

At the same time, federal officials have taken steps to try to prevent the shares from being oversold, frightened that a backlash could cause investment capital to dry up again. Thus the public offer of the Genentech shares was held up for several days, apparently after a ruling from the Securities and Exchange Commission that more details about the company's operations should be made public.

A revised prospectus issued by the company revealed that in the first half of 1980 , Genentech had a revenue of $\$ 3.8$ million, of which most came from research contracts, and earnings totalled only $\$ 80,000$. Almost two-thirds of the contracts came from three pharmaceutical companies - A.G. Kabi of Sweden, Eli Lilly and Hoffman La Roche - with whom Genentech is working on human growth hormone, insulin and interferon respectively. The prospectus also revealed that the three companies will not be required to pay any royalties to Genentech after their research agreements expire. Although the agreements are described as "long-term", no further details are given.

Although several Wall Street analysts have claimed that the enthusiasm for the Genentech shares showed that the stock market was reviving, others added notes of caution. Half-way through the first day of trading, shares dropped from $\$ 80$ to $\$ 74$ following warnings from a senior partner of a major investment house that the explosive activity might be a "danger signal" and that "it will attract issues of lesser quality where an attempt will be made to create the same aura of scarcity".

David Dickson

\section{European universities}

European universities seem uniformly to be heading for demographic trouble. According to a 15-nation study commissioned by the European Science Foundation (ESF), European universities have too many academics in the younger age groups and consequently too small a rate of recruitment to university staffs. To make things worse, there is a prospect of falling student numbers as a consequence of low birthrates since 1970 .

The report urges "concrete corrective action" to avoid an "irreparable" loss of research talent in the immediate future and, in the longer run, a shortage of trained scientists for the economy. The rate of new recruitment to most university teaching and research staffs is estimated at less then half the 3 per cent per annum required to maintain a flat age distribution.

The decline of the European birthrate since 1970 is potentially a political threat to the universities. The report points out that unless a greater proportion of the age group elects for university education, enrolments will fall, teacher-student ratios will rise and governments will be tempted to cut university budgets.

Superficially, France may be the most seriously affected, with the most unbalanced age distribution among present academic staffs (see graphs). In 1977, 46 per cent of French uiniversity teaching staffs were aged $30-40$, and retirement rates will average only 1.3 per cent a year over the next five years. But France is also among the most active in correcting the problem. In 1975, the Centre National de la Recherche Scientifique set itself a target of creating 3 per cent new posts a year within a staff of some 8,000 researchers. After a shaky start in 1978-79, recruitment seems likely to rise once more to 3 per cent, with consequent benefits for mobility among scientists.

Switzerland is at the other end of the spectrum. Retirements from the universities generate a 2.3 per cent annual demand for replacements in 1981-85, and thereafter more than 3 per cent.

In Germany, replacement demand is estimated at 1.5 per cent a year between now and 1985. The falling birthrate -

\section{No room below} down by 40 per cent in the period $1967-77$

- will be especially troublesome. The "Heisenberg scheme" introduced in 1978 to increase the academic pool by 1 per cent a year, leaves much to be desired. Pay is relatively poor, contracts terminate after 5 years and in any case the most able get the few professorships on offer and leave the scheme.

Stock of permanent academic staff universities in seven European cou.

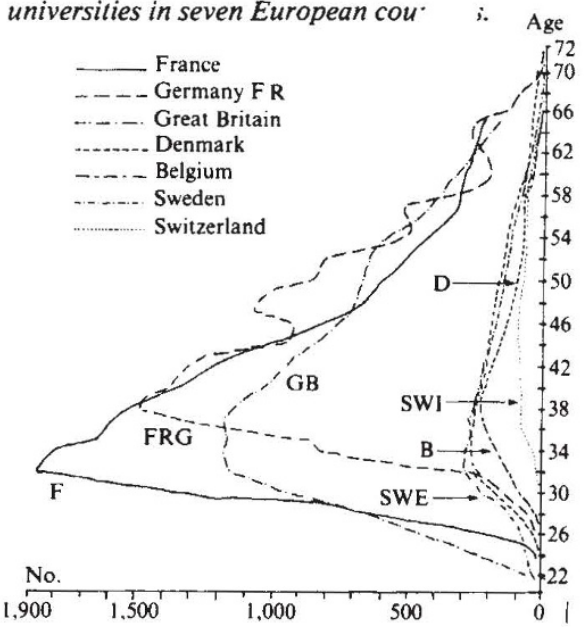

In the United Kingdom, the annual replacement rate is expected to be around 1.6 per cent, not reaching 3 per cent until the end of the century. Some 54 per cent of UK university staffs are between 30 and $\mathbf{4 5}$ years old. But, like France, the United Kingdom - and particularly the Science Research Council - has been at pains to do something about it. This year, the SRC is expected to make available 15 "Special Release Fellowships", which will pay professional salaries to senior academics often burdened by administration - to return to full-time research, while the monies thus released to the university will be used to employ a larger number of young researchers.

Of other countries studied, Belgium is in a particularly difficult position: 43 per cent of its university scientific staff are on shortterm contracts (compared with 61 per cent in government research institutions) and the majority of these are under 30 years old. Replacement demand for permanent positions is around 2 per cent, higher than most countries, but ESF has discovered no existing schemes in Belgium to tackle scientific unemployment. Denmark, with similar problems to most other countries, has proposals but no action; and Sweden,

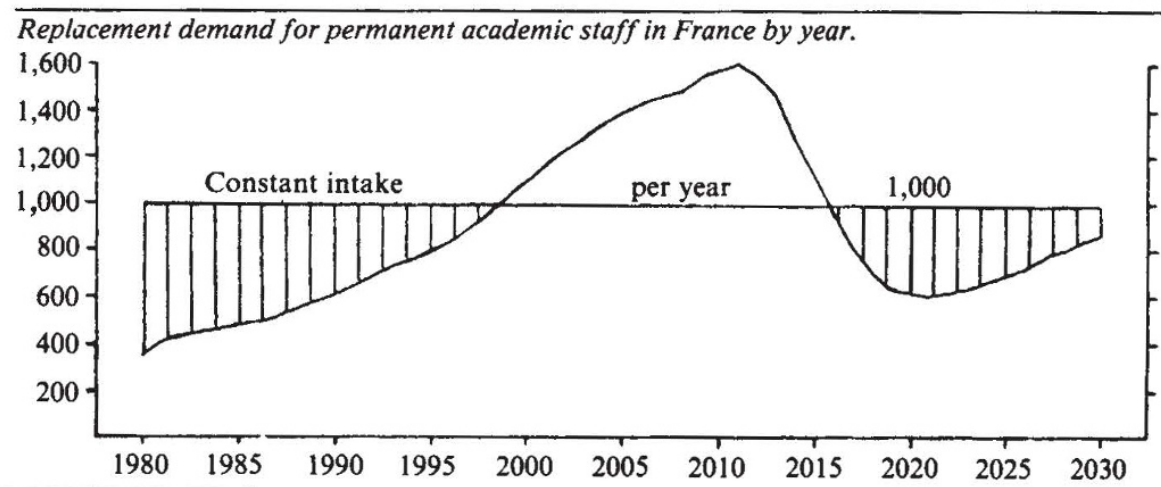

